\title{
Fungal and chemical diversity in hay and wrapped haylage for equine feed
}

\author{
Andersen, Birgitte; Phippen, Christopher; Frisvad, Jens C.; Emery, Sue; Eustace, Robert A.
}

Published in:

Mycotoxin Research

Link to article, DOI:

$10.1007 / \mathrm{s} 12550-019-00377-5$

Publication date:

2020

Document Version

Peer reviewed version

Link back to DTU Orbit

Citation (APA):

Andersen, B., Phippen, C., Frisvad, J. C., Emery, S., \& Eustace, R. A. (2020). Fungal and chemical diversity in hay and wrapped haylage for equine feed. Mycotoxin Research, 36, 159-172. https://doi.org/10.1007/s12550019-00377-5

\section{General rights}

Copyright and moral rights for the publications made accessible in the public portal are retained by the authors and/or other copyright owners and it is a condition of accessing publications that users recognise and abide by the legal requirements associated with these rights.

- Users may download and print one copy of any publication from the public portal for the purpose of private study or research.

- You may not further distribute the material or use it for any profit-making activity or commercial gain

- You may freely distribute the URL identifying the publication in the public portal

If you believe that this document breaches copyright please contact us providing details, and we will remove access to the work immediately and investigate your claim. 
${ }^{1}$ Department of Biotechnology and Biomedicine, Technical University of Denmark, DK-2800 Kgs. Lyngby,

5 Denmark.

${ }^{2}$ The Laminitis Clinic, Mead House, Dauntsey, Chippenham, Wiltshire SN15 4JA, United Kingdom

*author to whom correspondence should be addressed

Key words: Horses, ponies, mycotoxins, roquefortine, laminitis, metabolite profiling, adverse health effects

\section{Abstract}

The presence of fungi and mycotoxins in silage (fermented maize) for cattle and other ruminants have been studied extensively compared to wrapped haylage (fermented grass) for horses and other monogastric animals. The purpose of this work was to examine the fungal diversity of wrapped haylage and conventional hay and to analyse the forage sample for fungal metabolites. Faeces samples were also analysed to study the fate of fungi and metabolites. Fungal diversity of the samples was determined by direct plating on DG18, V8 and MEA and chemical analyses were done using LC-MS/MS. The results show that Sordaria fimicola was common in both hay and haylage, while Penicillium spp. was prevalent in haylage and Aspergillus spp. in hay. Communiols were found in all types of samples together with gliocladic acid. Roquefortines and fumigaclavines were found in haylage with no visible fungal growth, but not in hay. In haylage hot spot samples a series of Penicillium metabolites were detected: Andrastins, fumigaclavines, isofumigaclavines, marcfortines, mycophenolic acid, PR toxins and roquefortines. Penicillium solitum was 
found repeatedly in haylage and haylage hot spot samples and viridicatols were detected in a hot spot sample, which has not been reported before. Even haylage with no visible fungal growth contained more metabolites than hay. Individually, the metabolites detected in haylage may, in high doses, be mutagenic, neurotoxic or immunosuppressive; but the synergistic effect of small doses may also have other or greater negative health effects on equines than on ruminants.

\section{Introduction}

Equines, being monogastric animals, are considered to be more sensitive to fungi and mycotoxins in their forage than ruminants (Wambacq et al. 2015) and several studies describe cases of leukoencephalomalacia and stachybotryotoxicosis in equines caused by fumonisins (Fusarium spp.) and trichothecenes (Fusarium and Stachybotrys spp.) resulting in both acute and chronic toxicoses and death (Le Bars and Le Bars 1996; Liesener et al. 2010; Vendruscolo et al. 2016; Pitt and Miller 2017). In vitro studies on lameness (laminitis) in horses found that fumonisin B1 induced lamellar separation in the hoofs (Reisinger et al 2016) and in vivo studies found that juglone, the active compound in Black walnut (Juglans nigra) husks, could cause laminitis within 12 hours (Galey et al 1991). Furthermore, Hanche-Olsen et al. (2008) suggested that forage of poor microbial quality may be involved in hind limb lameness (acquired equine polyneuropathy).

Traditionally, equine forage has been hay, grain and grass, but since the 1980's, fermented grass, wrapped in bales (haylage) has partially or totally replaced hay for the feeding of equines in Northern Europe (Müller 2005; 2018; Müller et al. 2011; Schenk et al. 2018). One reason for replacing hay with haylage is that if the animal has respiratory problems (e.g. equine asthma or chronic obstructive pulmonary disease) feeding haylage avoids the dust from old or mouldy hay (Thomson and McPherson 1983). Hay dust has been shown to contain high levels of Aspergillus and Penicillium spp. spores, but no mycotoxins (Seguin et al. 2010). Another reason why haylage production and consumption has increased is convenience; grass for wrapping can be processed when it is moist and bales kept in plastic can be stored outside, whereas conventional hay This is a pre-print of an article published in Mycotoxin Research. The final authenticated version is available online at: https://doi.org/10.1007/s12550-019-00377-5. Page 2 
has to dry in the field and is stored indoors under dry conditions (Coblenz and Akins, 2018; Schenk et al. 2018).

Although mycotoxins in fermented maize (silage) for cattle have been studied extensively (Alonso et al. 2013; Storm et al. 2014), less is known about the fungal diversity and fungal metabolites in hay and haylage for equines (Müller et al. 2007; Liesener et al., 2010; Séguin et al. 2010; 2012; Müller, 2018; Schenk et al. 2018). Maize ears are prone to Aspergillus and Fusarium infection in the field (Shotwell et al. 1980; Young and Miller 1985), which can be carried over in the silage, whereas grasses in the field may be colonized by other fungal genera. Silage and haylage, on the other hand, are mostly associated with P. roqueforti and roquefortines (Sumarah et al. 2005), but the authors also suggest $P$. paneum and marcfortines are more associated with haylage in colder climates. O'Brien et al. (2006) analysed baled grass silage for Penicillium metabolites and found marcfortine A, mycophenolic acid and andrastin A, while Séguin et al. (2012) analysed hay and haylage samples for the classic mycotoxins and found zearalenone. Studies on forage derived from grass have so far focussed on the presence of either specific fungal species or mycotoxins and not the overall fungal growth and metabolite production.

The purposes of this study were therefore 1) to characterize the fungal diversity of hay and haylage and isolate the most frequent occurring filamentous fungi, 2) to qualitatively analyse hay and haylage samples for mycotoxins and other bioactive fungal metabolites produced by the most frequent fungi and 3) to characterize and analyse the faeces from ponies fed either hay or haylage for residual fungal spores and metabolites.

\section{Materials and Methods}

Project set-up. This project commenced in 2011 and comprises 20 Welsh ponies born between 2007 and 2009. Throughout the project all 20 ponies were housed in the same barn in two separate pens. One group of 10 ponies was fed haylage and the other 10 ponies were fed hay. When access was allowed to pasture 
(May 16 to November 22, 2018) the ponies went into separate paddocks in the same field. Before turn out and on return to the barn they were fed the forage appropriate to their group, every day.

Forage samples. Hay was grown on the study site from permanent pasture containing Creeping Bent (Agrostis stolonifera), Rough-stalked meadow grass (Poa trivialis) and Yorkshire Fog (Holcus lanatus). Less dominant but visible grass species included Meadow Brome (Bromus comutatus) and Annual meadow grass (Poa annua) and there was very little evidence of any ryegrass (Lolium spp.). Grass was cut, spread, rowed up and baled within three to four days. Hay was harvested in 2016 and 2018 and stored as oblong bales (280 kg). Haylage was purchased commercially (Marksway HorseHage, Paignton, Devon) made from short term ryegrass leys (Lolium spp). Haylage was provided as small individually wrapped bales (14 kg) produced in 2017. Forage (hay and haylage) samples were collected by randomly grapping handfuls from the bale during distribution to ponies. All sampling to place between March and September 2018 (Table 1).

Faeces samples. Faeces from three ponies in each group were included in the study in order to follow the fate of fungi and metabolites found in the forage. Faeces were collected within two minutes after normal defaecation, four times during 2018 (Table 1) from ponies fed with hay (\# 1, 6 and 15) and ponies fed haylage (\# 12, 13 and 14).

Haylage hot spot samples. Hot spot samples (haylage with visible fungal/mould growth) from older haylage bales sampled in 2013, 2014 and 2016 were also included in the study as worst case samples in order to know which fungi and metabolites to analyse for in the forage samples. Hot spot samples had been frozen at $-80^{\circ} \mathrm{C}$ in the interim.

Sample delivery and treatment. Samples of hay and haylage were shipped from England to Denmark via courier in four instalments (Table 1 ) in chilled boxes and kept at $0{ }^{\circ} \mathrm{C}$ until the next day when samples were treated. Haylage hot spots and faeces samples were shipped frozen and left to thaw in the fridge overnight prior to treatment.

This is a pre-print of an article published in Mycotoxin Research. The final authenticated version is available online at: https://doi.org/10.1007/s12550-019-00377-5. Page 4 
Growth media. All samples were plated out onto three different media for fungal detection: V8 agar (Campbell's V8 juice: $175 \mathrm{~mL}$ V8 ${ }^{\circledR}$ vegetable juice original, $3 \mathrm{~g}$ calcium carbonate, $20 \mathrm{~g}$ agar, $0.05 \mathrm{~g}$ chloramphenicol, $0.01 \mathrm{~g}$ zinc sulphate, $0.005 \mathrm{~g}$ copper sulphate, $825 \mathrm{ml}$ water, $0.05 \mathrm{~g}$ chlortetracycline (added after autoclaving), Samson et al. 2010), DG18 agar (Dichloran 18 \% Glycerol: 31.5 g dichloranglycerol-agar-base (Oxoid), $220 \mathrm{~g}$ glycerol (anhydrous), $0.05 \mathrm{~g}$ chloramphenicol, $0.01 \mathrm{~g}$ zinc sulphate, 0.005 g copper sulphate, $1000 \mathrm{~mL}$ water, $0.05 \mathrm{~g}$ chlortetracycline (added after autoclaving), Samson et al. 2010) and MEA agar with antibiotics (Malt extract agar: $25 \mathrm{~g}$ malt extract (Oxoid), $10 \mathrm{~g}$ agar, $0.05 \mathrm{~g}$ chloramphenicol, $0.01 \mathrm{~g}$ zinc sulphate, $0.005 \mathrm{~g}$ copper sulphate, $1000 \mathrm{~mL}$ water, $0.05 \mathrm{~g}$ chlortetracycline (added after autoclaving)).

Fungal detection and identification. The forage sample was aseptically cut onto $2 \mathrm{~cm}$ pieces in sterile plastic bags and the thawed hot spot and faeces samples were broken up in sterile, empty Petri dishes prior to plating. Each sample was transferred to one plate of V8, DG18 and MEA (approximately $1 \mathrm{~g}$ on each plate) and incubated at $20^{\circ} \mathrm{C}$ in the dark. The plates were read after 5 days and representative fungal colonies were isolated for identification. The plates were read again after 10 days to ensure that slow growing fungi also were detected. The presence of fungal cultures on each plate was registered qualitatively at genus level and pooled over the three media. Representative fungal cultures of Aspergillus, Chaetomium, Fusarium, Paecilomyces, Penicillium, Sordaria and Wallemia spp. were isolated, inoculated on media specific for each genus and identified using micro- and macro-morphological according to Domsch et al. (2007), Samson et al. (2010) and Seifert et al. (2011). Extraction and metabolite profiling of fungi in pure culture was done according to Samson et al. (2010) and Frisvad and Thrane $(1987 ; 1993)$ as amended by Nielsen et al. (2011), Klitgaard et al. (2014) and Kildgaard et al. (2014). Yeasts were not identified because they are not known to produce mycotoxins or other secondary metabolites (Frisvad et al. 2008).

Metabolite extraction. All samples (haylage hot spot, haylage, hay and faeces) for metabolite analyses were freeze dried and crushed in sterile plastic bags. Each sample (approximately $3 \mathrm{~g}$ ) was transferred into 
a $50 \mathrm{~mL}$ Falcon tube and added $40 \mathrm{~mL}$ of ethyl acetate/isopropanol (3:1 v/v) with $1 \%$ formic acid and extracted ultrasonically for $20 \mathrm{~min}$. Then $10 \mathrm{~mL}$ of the extract was evaporated to dryness, re-dissolved in $500 \mu \mathrm{L}$ methanol and centrifuged. $300 \mu \mathrm{L}$ of extract was transferred to a HPLC vial and analysed the same day.

Chemical analyses. All extracts (pure fungal cultures, hot spot, forage and faeces) were analysed by UHPLC on an Agilent 1290 system (Agilent Technologies, Santa Clara, CA, USA) equipped with a $25 \mathrm{~cm} \times 2 \mathrm{~mm}$ ID, 2.6 $\mu \mathrm{M}$ Agilent Poroshell phenylhexyl column which was coupled to an Agilent 6545 quadrupole Time Of Flight (qTOF) high resolution mass spectrometer equipped with an electrospray source. The qTOF was operated in extended dynamic range mode at a resolution of 30,000 FWHM (Full-Width Half-Maximum). Separation of a $1 \mu \mathrm{L}$ subsample was performed at $60^{\circ} \mathrm{C}$ at a flow rate of $0.35 \mathrm{~mL} / \mathrm{min}$ using a linear gradient consisting of water (A) and acetonitrile (B) both buffered with $20 \mathrm{mM}$ formic acid, starting at $10 \% \mathrm{~B}$ and increased to $100 \%$ in $15 \mathrm{~min}$ where it was held for $2 \mathrm{~min}$, returned to $10 \%$ in $0.1 \mathrm{~min}$ and remaining for 3 min. The qTOF was operated in both positive and negative modes, scanning from $\mathrm{m} / \mathrm{z} 100$ to 1700 four times per second. Automatic MS/MS was also performed using three consecutive collision energies of 10, 20 and $40 \mathrm{eV}$ and with an isolation window of $\pm 0.7 \mathrm{Da}$ in both positive and negative modes, providing MS/MS spectra (m/z 30-1700) for all major peaks.

Data treatment. UHPLC-MS/MS data files were inspected for all regulated mycotoxins and all relevant secondary metabolites from the fungal species detected in this study by accurate mass screening of pseudomolecular ions. Furthermore, the MS/MS data was screened against an in-house library of 1600 known secondary metabolites and against the metabolite profiles of pure cultures of fungi isolated from the forage samples (Rasmussen et al. 2010; Nielsen et al. 2011; Kildgaard et al. 2014; Klitgaard et al. 2014). Qualitative data matrices were made for both fungal data (binary $1 / 0$ for presence/absence of fungal species) and for metabolite data (binary $1 / 0$ for presence/absence of metabolites) for all 27 samples (4 hay, 8 haylage, 8 pooled faeces and 7 hot spot samples). Both matrices were standardized and subjected to 
Principal Component Analysis (PCA) using The Unscrambler (CAMO, version X 10.0.1) multivariate statistical program package.

\section{Results}

\section{Fungal analyses}

Forage samples. The four hay samples (labelled H) were dry and without any smell when they arrived,

whereas the eight haylage samples (labelled W) were moist and most samples had a weak sour smell. None of the forage samples had any visible mould growth. The mycological analyses showed that hay samples in general had a larger biodiversity in fungal species than the haylage samples. The older hay samples $(\mathrm{H}-\mathrm{A}$ to $\mathrm{H}-\mathrm{C}$ ) Aspergillus spp., especially A. glaucus, A. montevidensis and A. pseudoglaucus (formerly known as Eurotium herbariorum, E. amstelodami and E. repens, respectively) (Fig. 1A) were prevalent followed by W-C) P. roqueforti (Fig. 1C) was prevalent followed by yeast (not identified), A. pseudoglaucus, whereas Fusarium poae was the most prevalent fungus. Aspergillus flavus (aflatoxin producer (Samson et al. 2010)) and A. niger (fumonisin and ochratoxin producer (Samson et al. 2010)) were only detected in low numbers in hay samples $\mathrm{H}-\mathrm{A}$ and $\mathrm{H}-\mathrm{C}$, respectively. Aspergillus fumigatus was only seen in low levels in older hay samples (H-A to $\mathrm{H}-\mathrm{C}$ ) and in one haylage sample (W-B3). The newer hay and haylage samples (H-D and W-D) were very different from their older counterparts. The hay sample again showed the greatest biodiversity with Alternaria and Epicoccum spp. as the most frequently occurring fungi compared to the haylage sample, which was low in fungal biodiversity (Figs. 2A and C). Common for the two types of forage were the presence of Sordaria fimicola in both older and newer samples (Table 2).

Faeces samples. All thawed faeces samples were firm and without any mouldy odour. The 24 faeces samples were analysed individually, but the three samples for ponies in the same group collected at the same time were very similar. Table 2 therefore shows the pooled results for the three ponies in the hay This is a pre-print of an article published in Mycotoxin Research. The final authenticated version is available online at: https://doi.org/10.1007/s12550-019-00377-5. Page 7 
group and in the haylage group at the four different collection dates (A-D). The mycological analyses showed that the fungal composition of the faeces samples from ponies fed hay were different from ponies that had been fed haylage. Faeces from ponies fed on older hay (Fig. 1B) showed a higher load of Aspergillus spp. (A. glaucus, A. montevidensis and A. versicolor) compared with the faeces from ponies fed on older haylage (Fig. 1D) where Penicillium spp. (P. expansum, P. palitans and P. solitum) were more frequent (Table 2). Both groups of ponies were put on pasture after the $\mathrm{C}$ samples had been collected and had access to hay or haylage from newer batches. The faeces samples collected 04 September 2018 (sampling D) from both ponies fed hay and haylage (Figs. 2B and D, respectively) were devoid of Aspergillus spp. However, in both samples (F-H-D and F-W-D) P. expansum, P. commune, P. crustosum and S. fimicola were detected (Table 2). In addition, the two samples contained Phoma and Zygomycetes spp.and unidentifiable, non-sporulating filamentous fungi.

Haylage hot spots samples. All seven thawed samples of the haylage hot spots had visible fungal growth and a strong mouldy and sour smell. The results from the mycological analyses showed that Penicillium roqueforti was found in all samples. In some samples $P$. paneum, $P$. solitum and Paecilomyces variotii were also detected (Table 3). No Aspergillus spp. or field fungi (Alternaria, Cladosporium and Fusarium spp.) were detected in any of the hot spot samples.

A Principal Component Analysis of the qualitative fungal growth (48 species) on all 27 samples (4 hay, 8 haylage, 8 faeces and 7 hot spot samples) showed that all faeces samples grouped together next to the three older hay samples and one older haylage sample (W-B3) and the new haylage sample (W-D) (Fig. 3). The new hay sample (H-D) and one haylage sample (W-B2) grouped by themselves and away from other samples since they did not contain any Aspergillus or Penicillium spp. All seven hot spot samples grouped together with five of the haylage samples, which all contained $P$. roqueforti.

\section{Mycotoxin analyses}

This is a pre-print of an article published in Mycotoxin Research. The final authenticated version is available online at: https://doi.org/10.1007/s12550-019-00377-5. Page 8 
Forage samples. Metabolites associated with different species of Chaetomium and Sordaria/Podospora

189

190

191

192

193

194

(Sordariales) were prevalent in both old and new forage types (Table 4), but lower in numbers in the new hay (H-D) and haylage (W-D) samples. Sordaricin and/or sordarins were found in all samples but one (H-C). Cochliodinol was found in the three older hay samples, while chaetoxanthone B was detected in all haylage samples, except W-B3. Metabolites from different Penicillium spp., on the other hand, varied with forage type and age. Asperphenamate, $\beta$-cyclopiazonic acid and penicillic acid were detected in the older hay samples ( $\mathrm{H}-\mathrm{A}$ to $\mathrm{H}-\mathrm{C})$ and roquefortine $\mathrm{C}$ and isofumigaclavine $\mathrm{A}$ in two haylage samples $(\mathrm{W}-\mathrm{C} 2$ and $\mathrm{W}-\mathrm{C} 3)$. No Penicillium metabolites were detected in the two new hay and haylage samples. Furthermore, Aspergillus metabolites such as emodin, methyl-emodin and nigragillin, were detected in both hay and haylage samples, whereas dihydromonacolin, associated to Monascus spp., was found in older haylage samples (W-B1, W-B3 and W-C1). Figure 4 compares the chromatograms of hay sample $\mathrm{H}-\mathrm{C}$ and haylage sample W-C2, but generally all haylage samples had the same profile with the same 6-8 peaks of sphingosine derivatives. All samples also contained communiols, linoleic acid and ergosterol and many peaks that could not be identified as fungal metabolites.

Faeces samples. Only a few fungal metabolites were detected in the faeces samples of ponies fed hay, while in faeces from ponies fed haylage more metabolites were detected (Table 4). Most common were metabolites produced by fungi in Sordariales: the Chaetomium metabolites communiols, gliocladic acid and longirostrerone A and the Podospora/Sordaria metabolite appenolide A together with various derivatives of sphingosine (e.g. dihydro-sphingosine) and linoleic acid. However, no ergosterol was detected. Enniatins were detected in faeces samples from animals feeding on the new forage samples (F-H-D and F-W-D) in both groups.

Haylage hot spots. The chemical analyses of the haylage hot spot samples showed the same Chaetomium, Podospora and Sordaria metabolites as in the forage samples. Additional Penicillium metabolites were, however, detected in the hot spot samples (Table 3). The mycotoxin PR toxin, produced by P. roqueforti, 
was detected in one sample (W-hs-2). Other metabolites from P. roqueforti (andrastins, isofumigaclavin A, mycophenolic acid, roquefortines $C$ and $D$ ) were found in six of the samples, while $P$. solitum metabolites (cyclopenin, cyclopenol, cyclopeptin, viridicatin and viridicatol) were detected in sample W-hs-2. Metabolites specific for $P$. paneum (asperparaline A, marcfortines A and B) were also detected in three samples. No Penicillium metabolites were detected in W-hs-7. None of the Aspergillus metabolites that were detected in the forage samples were detected in the hot spot samples. As with forage and faeces samples, the hot spot samples also contained linoleic acid and ergosterol and various derivatives of sphingosine (e.g. dihydro-sphingosine). None of the regulated mycotoxins (aflatoxins, citrinin, fumonisins, ochratoxin or trichothecenes) were detected in any of the 27 samples tested. Screening all 27 samples sphinganine, which is a precursor for fumonisin B1, lolitrem B from ryegrass and juglone, but gave negative results.

A Principal Component Analysis of the qualitative metabolite production (93 known and unknown fungal compounds) across all 27 samples ( 4 hay, 8 haylage, 8 faeces and 7 haylage hot spot samples) shows that the old hay samples grouped together due to the presence of cochliodinol, $\beta$-cyclopiazonic acid and asperphenamate (Fig. 5). The new hay and haylage samples (H-D and W-D) grouped away from other samples due to the absence of Penicillium metabolites and the faeces samples grouped together and away from the forage samples due to the low number of fungal metabolites detected. Again the multivariate analyses showed that all seven hot spot samples grouped together with seven old haylage samples, which all showed similar metabolite profiles including roquefortines, chaetoquadrins and chaetoxanthone.

\section{Discussion}

234 The results of the chemical analyses did not show any of the regulated mycotoxins (aflatoxin, fumonisins, ochratoxin, patulin or trichothecenes) in any samples in this study, but fungi capable of producing these 
mycotoxins (Aspergillus flavus, A. niger, Fusarium poae and Penicillium paneum) were detected together with a broad range of field and storage fungi and their metabolites.

The results suggest that the raw materials (grass) for both hay and haylage start out with similar mycobiota from the field. Sordariales (Chaetomium, Podospora and Sordaria spp.) and/or their metabolites were found in both hay and haylage. This suggests that some Chaetomium spp. may live as endophytes in grasses and survive long enough to produce metabolites, such as 3-epi-aureonitol, longirostrerones and globosumones (Panthama et al. 2011; Bashyal et al. 2007; Marwah et al. 2007; Shi et al. 2013; Qin et al. 2009). Species of Sordaria and the closely related Podospora, known as dung fungi (Bills et al. 2013; Sarrocco 2016), may either contaminate the grass during harvest and drying or may actually also be plant endophytes. They produce metabolites like appenolides and communiols (Wang et al. 1993; 1997; Che et al. 2004; 2005), which have antimicrobial effects (Bashyal et al. 2005; Marwah et al. 2007) but nothing is known about their toxicity to equines.

Hay. Different treatments and storage of grass favour different fungal contaminants. Hay, which is aerobic, dry and neutral in $\mathrm{pH}$, is more likely to be contaminated with fungal species that tolerate lower water activities, such as Aspergillus spp., formerly known as Eurotium spp., and Wallemia sebi. These species are not known to produce mycotoxins (Moss 1998; Chen et al. 2017), but they are able to produce exorbitant amounts of fungal spores that become airborne when the dry hay bales are moved and broken up. Walleminol, detected in one hay sample, is toxic to rat liver cells and baby hamster kidney cells, but no information is available on the effects on living animals (Moss 1998). Asperphenamate, emodin and nigragillin, found in both hay and haylage samples, are not considered toxic and have even been used in Oriental medicine (De Vries et al. 2005; Lin et al. 2014; Dong et al. 2016).

$\beta$-cyclopiazonic acid and penicillic acid that were found in two hay samples and in one haylage sample may have some toxic properties. In comparison to $\alpha$-cyclopiazonic acid ( $\alpha$-CPA), $\beta$-cyclopiazonic acid (= bissecodehydrocyclopiazonic acid) has been characterized as relatively non-toxic (Cole and Cox, 1981; Ostry 
et al. 2018). $\alpha$-CPA is a specific inhibitor of sarco-plasmic reticulum Ca2+-ATPase and has been studied in chickens, guinea pigs, mice, rats, pigs, dogs, monkeys, but not equines, and affects the alimentary tract, heart, kidney, liver, skeletal muscles and the nervous system (Ostry et al. 2018). Penicillic acid is cytotoxic (Cole and Cox, 1981, Gräbsch et al. 2006), but has a low oral toxicity (Malekinejad et al. 2015), and has mostly been recognized as a mycotoxin because of its co-occurrence with ochratoxin A (Stoev et al. 2004; Stoev 2015) and because of its toxicity to broiler chickens (Pazhanivel et al. 2015). It may indirectly affect equines because of its antimicrobial effect and its quorum sensing inhibition of bacteria (Rasmussen and Givskov 2006), possibly changing the gut microbiota. In general, dry hay seems more resistant to mycotoxin production compared to the humid haylage, which is corroborated by Gallo et al. (2015), which also showed that hay samples usually have lower toxin contents than their haylage counterparts.

Haylage. Haylage, as opposed to hay, is semi-anaerobic, moist and low in $\mathrm{pH}$, and therefore prone to fungal contaminants, such as Penicillium roqueforti that is known for its ability to grow at pH 2.7-3.0 (Kalai et al, 2017). Penicillium roqueforti and the closely related species $P$. paneum are particularly common in silage due to their tolerance to acetic acid, lactic acid, and quite high levels of carbon dioxide (Nielsen et al. 2006; O'Brien et al. 2006; Ogunade et al. 2018). In earlier studies on whole-plant maize silage aflatoxin $B_{1}$, diacetoxyscirpenol, fumonisin $B_{1}$ and $B_{2}$ and zearalenone, have been detected (Alonso et al. 2013; Ogunade et al. 2018), but Aspergillus flavus and $A$. niger were not detected in any haylage samples and Fusarium poae only in one sample in this study. It is also known that $A$. fumigatus can grow in maize silage, when the pH is higher than 3.5 (Alonso et al. 2017); it was found in one haylage sample, but the acidic conditions are usually not conducive for mycotoxin production (Northolt and Bullerman, 1982).

However, in the haylage samples in this study, cocktails of bioactive Penicillium metabolites were detected. This was especially evident in the haylage hot spot samples where $P$. roqueforti, $P$. paneum and Paecilomyces variotii were found. These species are known to produce mycotoxins, such as PR-toxin, patulin and viriditoxin (Cole and Cox, 1981; Samson et al. 2010). PR-toxin was detected in one hot spot 
sample in this study, but other Penicillium metabolites like andrastins, asperparaline A, isofumigaclavine, marcfortines, mycophenolic acid, rugulovasines and roquefortines, were detected in haylage and/or haylage hot spots. Penicillium solitum, which has not previously been associated with silage or haylage, was found in two hot spot samples and its metabolites, viridicatols (= cyclopenins (Samson et al. 2010)), in one hot spot sample. These metabolites can also be produced by P. crustosum (Samson et al. 2010), which was detected in a haylage sample. These findings suggest that viridicatols should be taken in to consideration when assessing the cocktail effect.

PR-toxin, possibly the most toxic metabolite from P. roqueforti, is rarely detected in silage (Gallo et al. 2015), whereas roquefortine $C$ and mycophenolic acid are encountered often (Auerbach et al. 1998; O'Brien et al. 2006; Storm et al. 2008, 2010, 2014; Dubey et al. 2018). PR-toxin is hepato- and nephrotoxic to mice and has been claimed to be potentially carcinogenic (Dubey et al. 2018). The data on ruminants indicate toxic effects, but without affecting the gut microbiota (Dubey et al. 2018). Roquefortine C was initially considered to be neurotoxic, but the data were based on intraperitoneally injected samples (Polonsky et al. 1977). Recent data suggest that roquefortine $C$ is not cytotoxic (Larsen et al. 2002) and that ingestion of roquefortine $C$ has little toxic effect on cows and sheep (Ogunade et al. 2018). Mycophenolic acid appears to be orally non-toxic for vertebrates, but it has a strong immune-lowering effect (Bentley, 2000). Rugulovasines A and B produced by P. commune (Frisvad et al. 2004) are ergot alkaloids that have been shown to be acutely toxic to poultry (Dorner et al. 1980; Fabian et al. 2018), and have been classified as mycotoxins (Skóra et al. 2017). There is no reliable toxicity data on the andrastins (both P. paneum and P. roqueforti), isofumigaclavine (P. roqueforti) or on the marcfortines (P. paneum). In general, little is known about the toxicity of bioactive fungal metabolites and mycotoxins to equines.

Dihydromonacolin, which is produced by Monascus ruber (Nakamura et al 1990), was detected in three haylage samples. Monascus ruber is known to contaminate maize silage and produce citrinin (Rasmussen et 
al 2011, Gallo et al 2015). Neither fungus nor citrinin were detected in any sample, but the presence of dihydromonacolin suggests that $M$. ruber may be common in haylage.

Penicillium solitum and P. crustosum, found in haylage or hot spot samples, have not previously been regarded as resistant to acetic acid. The occasional appearance of these Penicillia in haylage suggests that the $\mathrm{pH}$ and oxygen levels were not as low as they should be to prevent fungal growth and metabolite production. In general, moist haylage is more susceptible to mycotoxin production than dry hay; it is therefore very important that the fermentation has been successful and that the plastic wrapping has not During work with the haylage samples in the laboratory it became evident that especially $P$. roqueforti spores became airborne when the samples were handled, similar to Aspergillus and Wallemia spp. in the hay samples. This adds another complicating factor to equine health, since inhalation increases the toxicity of roquefortine $\mathrm{C}$ and mycophenolic acid. These metabolites can induce significant inflammatory responses in mouse lungs if inhaled (Rand et al. 2005). Thus inhaling spores coated with roquefortine C, mycophenolic acid and other bioactive metabolites from $P$. roqueforti and $P$. paneum growing and sporulating in haylage may pose an additional health risk to equines.

Faeces. The diversity and succession of fungal species, especially Aspergillus, Penicillium and Sordariales spp. in the faeces seem to reflect the different forage types fed to the ponies as well as the age/quality of the forage. These results suggest that fungal spores can survive the travel through the gut, as seeds can in birds, and that the spore composition in the faeces may be predictive for forage type and quality. The results also show that the number of different fungal metabolites, including linoleic acid, in the faeces samples is low, suggesting that most metabolites and ergosterol present in the forage have either been broken down by the anaerobic microbes in the gut or been taken up by the ponies together with nutrients in the forage. 
Metabolite cocktails and adverse health effect in equines. The results in this study indicate that the distribution of metabolites can be very inhomogeneous within a haylage bale and between bales. Furthermore, metabolite production can have occurred in bales even when there is no visible fungal growth, which O'Brien et al. (2006) also found. The principal component analyses (figs. 3 and 5) show that haylage samples have the same profile of fungal metabolites as the hot spots, which suggest that haylage bales may contain many of the same fungal species and metabolites as the hot spot samples.

Equines that are fed haylage are therefore exposed to a different cocktail of fungal metabolites via the forage than equines fed hay, which may - over the years - have a negative impact of their health. Whether the presence of immunosuppressive mycophenolic acid in some haylage samples, is paving the way for equine infections, is not known either. Suppressed immune function by fungal metabolites may eventually decrease resistance to, or reactivate chronic exposures to, mycotoxins (Oswald et al. 2005). Furthermore, the lactic acid bacterial fermentation seems to release large amounts of sphingosines from the plant material and promote growth of yeasts, but it is not known if these compounds and organisms have a positive or a negative health effect on equines.

Little work has been done on the effects on ingestion and inhalation of mycotoxins and other bioactive metabolites in equines. Also the naphthoquinones, similar to juglone, may have negative effects and can be produced by a broad variety of fungi such as Fusarium and Penicillium (Medentsev and Akimenko1998). More research is needed to disclose if fungal metabolites and mycotoxins - especially metabolites from Penicillium crustosum, $P$. paneum, $P$. roqueforti and $P$. solitum together with plant sphingosines and yeasts - are contributory factors to neurologic syndromes like acquired equine polyneuropathy, laminitis and Cushing's disease.

\section{Acknowledgements}

The authors wish to thank The Laminitis Trust for their financial support and Lisette Knoth-Nielsen for technical assistance.

This is a pre-print of an article published in Mycotoxin Research. The final authenticated version is available online at: https://doi.org/10.1007/s12550-019-00377-5. Page 15 
354

\section{Funding information}

This study was supported by The Laminitis Trust.

\section{Compliance with ethical standards}

Conflicts of interest

The last author is a Trustee of the Laminitis Trust.

\section{References}

Alonso V, Cavaglieri L, Ramos AJ, Torres A, Marin S (2017) Modelling the effect of pH and water activity in the growth of Aspergillus fumigatus isolated from corn silage. J Appl Microbiol 122: 1048-1056. https://doi.org/10.1111/jam.13395

Alonso VA, Pereyra CM, Keller LAM, Dalcero AM, Rosa CAR, Chiacchiera SM, Cavaglieri LR (2013) Fungi and mycotoxins in silage: an overview. J Appl Microbiol 115:637-643. https://doi.org/10.1111/jam.12178

Auerbach H, Oldenburg E, Weissbach F (1998) Incidence of Penicillium roqueforti and roquefortine C in silages. J Sci Food Agric 76:565-572. https://doi.org/10.1002/(SICI)1097-0010(199804)76:4<565::AIDJCFA990>3.0.COI2-6

Bashyal BP, Burns AM, Liu MX, Paranagama PA, Seliga CJ, Turbyville TJ, Wijeratne EMK, Zhan J, Gunatilaka MK, Arnold AE, Faeth SH, Whitesell L, Gunitilaka AAL (2007) Discovery of small molecule bioactive agents from endophytic fungi of the Sonoran Desert. $6^{\text {th }}$ International Symposium on fungal endophytes, Grassland Research Practices Series No. 13, New Zealand Grassland Association, Dunedin, pp 211-214.

Bashyal BP, Wijeratne EK, Faeth SH, Gunatilaka AL (2005) Globosumones A- C, cytotoxic orsellinic acid esters from the Sonoran desert endophytic fungus Chaetomium globosum. J Nat Prod 68:724-728. https://doi.org/10.1021/np058014b

This is a pre-print of an article published in Mycotoxin Research. The final authenticated version is available online at: https://doi.org/10.1007/s12550-019-00377-5. Page 16 
Bentley R (2000) Mycophenolic acid: a one hundred year odyssey from antibiotic to immunosuppressant. Chem Rev 100:3801-3825. https://doi.org/10.1021/cr9900976

Bills GF, Gloer JB, An Z (2013) Coprophilous fungi: antibiotic discovery and functions in an underexplored arena of microbial defensive mutualism. Cur Op Microbiol 16:549-565. https://doi.org/10.1016/j.mib.2013.08.001

Che Y, Araujo AR, Gloer JB, Scott JA, Malloch D (2005) Communiols E- H: new polyketide metabolites from the coprophilous fungus Podospora communis. J Nat Prod 68:435-438. https://doi.org/10.1021/np049592f

Che Y, Gloer JB, Scott JA, Malloch D (2004) Communiols A-D: new mono-and bis-tetrahydrofuran derivatives from the coprophilous fungus Podospora communis. Tetrahedron Lett 45:6891-6894. https://doi.org/10.1016/tetlet.2004.07.093

Chen AJ, Hubka V, Frisvad JC, Visagie CM, Houbraken J, Meijer M, Varga J, Rasine D, Jurjević Ž, Kubátová, A, Sklenáŕ F, Samson RA (2017) Polyphasic taxonomy of Aspergillus section Aspergillus (formerly Eurotium) and its occurrence in indoor environment and food. Stud Mycol 88:37-135. https://doi.org/10.1016/i.simyco.2007.07.001

Coblenz WK, Akins MS (2018) Silage review: Recent advances and future technologies for baled silages. Journal of Dairy Science 101:4075-4092. https://doi.org/10.3168/jds.2017-13708

Cole RJ, Cox RH (1981) Handbook of toxic fungal metabolites. Academic Press, New York.

De Vries RP, Frisvad JC, van de Vondervoort PJ, Burgers K, Kuijpers AF, Samson RA, Visser, J (2005) Aspergillus vadensis, a new species of the group of black Aspergilli. Antonie Van Leeuwenhoek 87:195-203. https://doi.org/10.1007/s10482-004-3194-y

Domsch KH, Gams W, Anderson T-H (2007) Compendium of soil fungi. $2^{\text {nd }}$ ed. IHW-Verlag, Eching. 
Dong X-X, Fu J, Yin X, Cao S, Li X-B, Lin L, Cao S-L, Li X-C, Lin L-F, Huyiligeqi, Ni, J (2016) Emodin: a review of its pharmacology, toxicity and pharmacokinetics. Phytother Res 30:1207-1218. https://doi.org/10.1002//ptr.5631

Dorner J W, Cole RJ, Hill R, Wicklow D, Cox RH (1980) Penicillium rubrum and Penicillium biforme, new sources of rugulovasines A and B. Appl Environ Microbiol 40:685-687.

Dubey MK, Aamir M, Kaushik MS, Khare S, Meena M, Singh S, Upadhyay, R S (2018) PR Toxin-Biosynthesis, Genetic Regulation, Toxicological Potential, Prevention and Control Measures: Overview and Challenges. Front Pharmacol 9:288. https://doi.org/10.3389/fphar.2018.00288

Fabian SJ, Maust MD, Panaccione DG (2018) Ergot Alkaloid Synthesis Capacity of Penicillium camemberti. Appl Environ Microbiol 84:e01583-18. https://doi.org/10.1128/AEM.61583-18

Frisvad JC, Thrane U (1987) Standardized High Performance Liquid Chromatography of 182 mycotoxins and other fungal metabolites based on alkylphenone indices and UV VIS spectra (diode array detection). J Chromatogr 404:195 214. https://doi.org/10.1016/S0021-9673(01)86850-3

Frisvad JC, Thrane U (1993) Liquid column chromatography of mycotoxins. In: Betina V (ed): Chromatography of mycotoxins: techniques and applications. Journal of Chromatography Library 54, Elsevier, Amsterdam, pp 253-372.

Frisvad JC, Andersen B, Thrane U (2008) The use of secondary metabolite profiling in chemotaxonomy of filamentous fungi. Mycol Res 112:231-240. https://doi.org/10.1016/j.mycres.2007.08.018

Frisvad JC, Smedsgaard J, Larsen TO, Samson RA (2004) Mycotoxins, drugs and other extrolites produced by species in Penicillium subgenus Penicillium. Stud Mycol 49:201-241.

Galey FD, Whiteley HE, Goetz TE, Kuenstler AR, Davis CA, Beasley VR (1991) Black-walnut (Juglans nigra) toxicosis -a model for equine laminitis. J Comp Pathol 104:313-326. https://doi.org/10.1016/S00219975(08)80043-6

This is a pre-print of an article published in Mycotoxin Research. The final authenticated version is available online at: https://doi.org/10.1007/s12550-019-00377-5. Page 18 
Gallo A, Giuberti G, Frisvad JC, Bertuzzi T, Nielsen KF (2015) Review on mycotoxin issues in ruminants: occurrence in forages, effects of mycotoxin ingestion on health status and animal performance and practical strategies to counteract their negative effect. Toxins 7:3057-3111. https://doi.org/10.3390/toxins7083057

Gräbsch C, Wichmann G, Loffhagen N, Herbarth O, Müller A (2006) Cytotoxicity assessment of gliotoxin and penicillic acid in Tetrahymena pyriformis. EnvironToxicol 21:111-117. https://doi.org/10.1002/tox.20162

Hanche-Olsen S, Teige J, Skaar I, Ihler CF (2008) Polyneuropathy associated with forage sources in Norwegian horses. J Vet Intern Med 22:178-184. https://doi.org/10.1111/j.1532-950X.2008.00396.x

Kalai S, Anzala L, Bensoussan M, Dantigny P (2017) Modelling the effect of temperature, $\mathrm{pH}$, water activity, and organic acids on the germination time of Penicillium camemberti and Penicillium roqueforti conidia. Int J Food Microbiol 240:124-130. https://doi.org/10.1016/j.ijfoodmicro.2016.03.024

Kildgaard S, Mansson M, Dosen I, Klitgaard A, Frisvad JC, Larsen TO, Nielsen KF (2014) Accurate dereplication of bioactive secondary metabolites from marine-derived fungi by UHPLC-DAD-QTOFMS and MS/HRMS library. Mar Drugs 12:3681-3705. https://doi.org/10.3390/md12063681

Klitgaard A, Iversen A, Andersen MR, Larsen TO, Frisvad JC, Nielsen KF (2014) Aggressive dereplication using UHPLC-DAD-QTOF - screening extracts for up to 3000 fungal secondary metabolites. Anal Bioanal Chem 406:1933-1943. https://doi.org/10.1007/S00216-013-7582-x

Larsen TO, Gareis M, Frisvad JC (2002) Cell cytotoxicity and mycotoxin and secondary metabolite production by common Penicillia on cheese. J Agric Food Chem 50:6148-6152. https://doi.org/10.1021/jf020453i

Le Bars J, Le Bars P (1996) Recent acute and subacute mycotoxicoses recognized in France. Vet Res 27:383394.

This is a pre-print of an article published in Mycotoxin Research. The final authenticated version is available online at: https://doi.org/10.1007/s12550-019-00377-5. Page 19 
444 Liesener K, Curtui V, Dietrich R, Märtlbauer E, Usleber, E (2010) Mycotoxins in horse feed. Mycotoxin Res 26:23-30. https://doi.org/10.1007/S12550-009-0037-8

446 Lin S, He J, Jiang Y, Wu F, Wang H, Wu D, Sun J, Zhang D-D, Qu H-X, Yang B (2014) Production of nigragillin 447 and dihydrophaseic acid by biotransformation of litchi pericarp with Aspergillus awamori and their antioxidant activities. J Funct Foods 7:278-286. https://doi.org/10.1016/j.jff.2014.02.001

449

450

451

452

453

454

455

456

457

458

459

460

Malekinejad H, Aghazadeh-Attari J, Rezabakhsh A, Sattari M, Ghasemsoltani-Momtaz B (2015) Neurotoxicity of mycotoxins produced in vitro by Penicillium roqueforti isolated from maize and grass silage. Human Exper Toxicol 34:997-1005. https://doi.org/10.1177/0960327114565493

Marwah RG, Fatope MO, Deadman ML, Al-Maqbali YM, Husband J (2007) Musanahol: a new aureonitolrelated metabolite from a Chaetomium sp. Tetrahedron 63:8174-8180. https://doi.org/10.1016/j.tert.2007.05.119

Medentsev AG, Akimenko VK (1998) Naphthoquinone metabolites of the fungi. Phytochem 47:935-959. https://doi.org/10.1016/S0031-9422(98)80053-8

Moss MO (1998) Recent studies of mycotoxins. J Appl Microbiol 84: 62S-76S. https://doi.org/10.1046/j.1365-2672.1998.0840s162S.x

Müller CE (2005) Fermentation patterns of small-bale silage and haylage produced as feed for horses. Grass Forage Sci 60:109-118. https://doi.org/10.1111/j.1365-2494.2005.00457.x

Müller CE (2018) Silage and haylage for horses. Grass Forage Sci 73:815-827. https://doi.org/10.1111/gfs.12387

Müller CE, Hultén C, Gröndahl G (2011) Assessment of hygienic quality of haylage fed to healthy horses. Grass Forage Sci 66:453-463. https://doi.org/10.1111/j.1365-2494.2011.00803x

This is a pre-print of an article published in Mycotoxin Research. The final authenticated version is available online at: https://doi.org/10.1007/s12550-019-00377-5. Page 20 
Müller CE, Pauly TM, Udén P (2007) Storage of small bale silage and haylage-influence of storage period on fermentation variables and microbial composition. Grass Forage Sci 62:274-283. https://doi.org/10.1111/j-1365-2494.2007.00580x

Nakamura T, Komagata D, Murakawa S, Sakai K, Endo, A (1990) Isolation and biosynthesis of 3 $\alpha$-hydroxy-3, 5-dihydromonacolin L. J Antibiot 43: 1597-1600.

Nielsen KF, Frisvad JC, Sumarah M, Miller JD (2006) Production of metabolites from the Penicillium roqueforti complex. J Agric Food Chem 54:3756-3763. https://doi.org/10.1021/jf060114f

Nielsen KF, Månsson M, Rank C, Frisvad JC, Larsen TO (2011) Dereplication of microbial natural products by LC-DAD-TOFMS. J Nat Prod 74:2338-2348. https://doi.org/10.1021/np200254t

Northolt MD, Bullerman L B (1982) Prevention of mold growth and toxin production through control of environmental conditions. J Food Prot 45:519-526. https://doi.org/10.4315/0362-028X-45.6.519

O'Brien M, Nielsen KF, O'Kiely P, Forristal PD, Fuller HT, Frisvad, JC (2006) Mycotoxins and other secondary metabolites produced in vitro by Penicillium paneum Frisvad and Penicillium roqueforti Thom isolated from baled grass silage in Ireland. J Agric Food Chem 54:9268-9276. https://doi.org/10.1021/jf0621018

Ogunade IM, Martinez-Tuppia C, Qeiroz OCM, Jiang Y, Drouin P, Wu F, Vyas D, Adesogan AT (2018) Silage review: Mycotoxins in silage: Occurrence, effects, prevention and mitigation. J Dairy Sci 101:40344059. https://doi.org/10.3168/jds.2017-13788

Ostry V, Toman J, Grosse Y, Malir F (2018) Cyclopiazonic acid: 50th anniversary of its discovery. World Mycotoxin J 11:135-148. https://doi.org/10.3290/WMJ2017.2243

Oswald IP, Marin DE, Bouhet S, Pinton P, Taranu I, Accensi F (2005) Immunotoxicological risk of mycotoxins for domestic animals. Food Addit Contam 22:354-360. https://doi.org/10.1080/0265203030500058320

This is a pre-print of an article published in Mycotoxin Research. The final authenticated version is available online at: https://doi.org/10.1007/s12550-019-00377-5. Page 21 
Panthama N, Kanokmedhakul S, Kanokmedhakul K, Soytong, K (2011) Cytotoxic and antimalarial azaphilones from Chaetomium longirostre. J Nat Prod 74:2395-2399. https://doi.org/10.1021/np2004903

Pazhanivel N, Balachandran C, Muralimanohar B, Dhinakarraj G, Balakrishnan V, Kirubaharan,J J, Raja A (2015) Alleviative effect of gingerol on cell mediated and humoral immunity and immune organs against penicillic acid mycotoxicosis in broiler chickens. Int J Life Sci Pharma Res 5:L28-L34.

Pitt JI, Miller JD (2017) A concise history of mycotoxin research. J Agric Food Chem 65:7021-7033. https://doi.org/10.1021/acs.jafc.6b64494

Polonsky J, Merrien MA, Scott PM (1977) Roquefortine and isofumigaclavine A, alkaloids from Penicillium roqueforti. Ann Nutr l'Aliment 31:963-968.

Qin JC, Gao JM, Zhang YM, Yang SX, Bai MS, Ma YT, Laatsch H (2009) Polyhydroxylated steroids from an endophytic fungus, Chaetomium globosum ZY-22 isolated from Ginkgo biloba. Steroids 74:786-790. https://doi.org/10.1016/j.steroids.2009.04.011

Rand TG, Giles S, Flemming J, Miller JD, Puniani E (2005) Inflammatory and cytotoxic responses in mouse lungs exposed to purified toxins from building isolated Penicillium brevicompactum Dierckx and $P$. chrysogenum Thom. Toxicological Sciences 87:213-222. https://doi.org/10.1093/toxsci/kfi223

Rasmussen TB, Givskov M (2006) Quorum-sensing inhibitors as anti-pathogenic drugs. Int J Med Microbiol 296:149-161. https://doi.org/10.1016/j.ijmm.2006.02.005

Rasmussen RR, Rasmussen PH, Larsen TO, Bladt TT, Binderup ML (2011) In vitro cytotoxicity of fungi spoiling maize silage. Food Chem Toxicol 49:31-44. https://doi.org/10.1016/j.fct.2010.09.007

Rasmussen RR, Storm IMLD, Rasmussen PH, Smedsgaard J, Nielsen KF (2010) Multi-mycotoxin analysis of maize silage by LC-MS/MS. Anal Bioanal Chem 397:765-776. https://doi.org/10.1007/S00216-010$3545-7$

This is a pre-print of an article published in Mycotoxin Research. The final authenticated version is available online at: https://doi.org/10.1007/s12550-019-00377-5. Page 22 
Reisinger N, Dohnal I, NagI V, Schaumberger S, Schatzmayr G, Mayer E (2016) Fumonisin B1 (FB1) induces lamellar separation and alters sphingolipid metabolism of in vitro cultured hoof explants. Toxins 8:89. https://doi.org/10.1016/j.toxlet.2019.01.013

Samson RA, Houbraken J, Thrane U, Frisvad JC, Andersen B (2010) Food and indoor fungi. $1^{\text {st }}$ edn CBS Laboratory Manual Series 2. CBS-Fungal Biodiversity Centre, Utrecht.

Sarrocco S (2016) Dung-inhabiting fungi: a potential reservoir of novel secondary metabolites for the control of plant pathogens. Pest Manag Sci 72:643-652. https://doi.org/10.1002/PS.4206

Schenk J, Djurle A, Jensen DF, Müller C, O’Brien M, Spörndly R (2018) Filamentous fungi in wrapped forages determined with different sampling and culturing methods. Grass Forage Sci 74:29-41. https://doi.org/10.1111/gfs.12399

Séguin V, Garon D, Lemauviel-Lavenant S, Lanier C, Bouchart V, Gallard Y, Blanchet B, Diquelou S, Personeni E, Ourry A (2012) How to improve the hygienic quality of forages for horse feeding. J Sci Food Agric 92:975-986. https://doi.org/10.1002/jsfa.4680

Séguin V, Lemauviel-Lavenant S, Garon D, Bouchart V, Gallard Y, Blanchet B, Diquelou S, Personeni E, Gauduchon P, Ourry, A (2010) An evaluation of the hygienic quality in single-species hays and commercial forages used in equine nutrition. Grass Forage Sci 65:304-317. https://doi.org/10.1111/j.1365-2494.2010.00751

Seifert KA, Morgan-Jones G, Gams W, Kendrick B (2011) The genera of Hyphomycetes. CBS-Fungal Biodiversity Centre, Utrecht.

Shi Y, Zhang X, Lou K (2013) Isolation, characterization, and insecticidal activity of an endophyte of drunken horse grass, Achnatherum inebrians. J Insect Sci 13:151.

This is a pre-print of an article published in Mycotoxin Research. The final authenticated version is available online at: https://doi.org/10.1007/s12550-019-00377-5. Page 23 
Skóra J, Sulyok M, Nowak A, Otlewska A, Gutarowska B (2017) Toxinogenicity and cytotoxicity of Alternaria, Aspergillus and Penicillium moulds isolated from working environments. Int J Environ Sci Technol 14:595-608. https://doi.org/10.1007/S13762-016-1172-3

Stoev SD (2015) Foodborne mycotoxicoses, risk assessment and underestimated hazard of masked mycotoxins and joint mycotoxin effects or interaction. Environ Toxicol Pharmacol 39:794-809. https://doi.org/10.1016/j.etap.2015.01.022

Stoev SD, Stefanov M, Radic B, Domijan AM, Peraica M (2004) Experimental mycotoxicosis in chickens induced by ochratoxin A and penicillic acid and intervention with natural plant extracts. Vet Res Commun 28:727-746. https://doi.org/10.1023/B:VERC.0000045960.46678.d3

Storm IMLD, Kristensen NB, Raun BML, Smedsgaard J (2010) Dynamics in the microbiology of maize silage during whole-season storage. J Appl Microbiol 109:1017-1026. https://doi.org/10.1111/j.B652672.2010.04729x

Storm IMLD, Rasmussen RR, Rasmussen, PH (2014) Occurrence of pre- and post-harvest mycotoxins and other secondary metabolites in Danish maize silage. Toxins 6:2256-2269. https://doi.org/10.3390/toxin6082256

Storm IM, Sørensen JL, Rasmussen RR, Nielsen KF (2008) Mycotoxins in silage. Stewart Postharvest Rev 6:112.

Sumarah MW, Miller JD, Blackwell BA (2005) Isolation and metabolite production by Penicillium roqueforti, P. paneum and P. crustosum isolated in Canada. Mycopathologia 159: 571-577. https://doi.org/10.1007/s11046-005-5257-7

Thomson JR, McPherson EA (1983) Chronic obstructive pulmonary disease in the horse 2: Therapy. Equine Vet J 15:207-210. https://doi.org/10.1111/j.2042-3306.1983.tb01766.x 
554 Vendruscolo CP, Frias NC, de Carvalho CB, de Sá LRM, Belli CB, Baccarin RYA (2016) Leukoencephalomalacia 555 outbreak in horses due to consumption of contaminated hay. J Vet Int Med 30:1879.

$556 \quad$ https://doi.org/10.1111/jvim.14588

557 Wambacq E, Vanhoutte I, Audenaert K, De Gelder L, Haesaert G (2016) Occurrence, prevention and 558 remediation of toxigenic fungi and mycotoxins in silage: a review. J Sci Food Agric 96:2284-2302. $559 \quad$ https://doi.org/10.1002/jsfa.7565

560 Wang Y, Gloer JB, Scott JA, Malloch D (1993) Appenolides A, appendiculede B, appendiculide C: three new 561 antifungal furanones from the coprophilous fungus Podospora appendiculata. J Nat Prod 56:341-344. $562 \quad$ https://doi.org/10.1021/np50093a005

563 Wang HJ, Gloer KB, Gloer JB, Scott JA, Malloch D (1997) Anserinones A and B: new antifungal and 564 565 antibacterial benzoquinones from the coprophilous fungus Podospora anserina. J Nat Prod 60:629631. https://doi.org/10.1021/np970071k 
566 Table 1 The four collection times (A, B, C and D) in 2018 with dates, forage type (hay and wrapped haylage) 567 and faeces samples, which were analysed for fungal growth and mycotoxin production.

568

\begin{tabular}{|c|c|c|c|c|c|c|c|}
\hline \multicolumn{2}{|c|}{ Crop/production date } & \multicolumn{2}{|c|}{$\begin{array}{l}\text { Collection dates in } \\
2018\end{array}$} & \multicolumn{2}{|c|}{ Forage } & \multicolumn{2}{|l|}{ Faeces (F) } \\
\hline $\begin{array}{l}\text { Hay } \\
\text { (harvest year) }\end{array}$ & $\begin{array}{l}\text { Haylage } \\
\text { (batch number) }\end{array}$ & Code & Dates & $\begin{array}{l}\text { Hay } \\
\text { (H) }\end{array}$ & $\begin{array}{l}\text { Haylage } \\
\text { (W) }\end{array}$ & $\begin{array}{l}\text { Hay-ponies } \\
(\mathrm{F}-\mathrm{H}, \mathrm{n}=3)\end{array}$ & $\begin{array}{l}\text { Haylage-ponies } \\
(\mathrm{F}-\mathrm{W}, \mathrm{n}=3)\end{array}$ \\
\hline 2016 & $543-062465$ & $A$ & $\begin{array}{l}06 \text { March and } \\
07 \text { March }\end{array}$ & $\mathrm{H}-\mathrm{A}$ & W-A & F-H-A & F-W-A \\
\hline 2016 & $\begin{array}{l}543-062312 \\
543-062314 \\
543-062280\end{array}$ & B & $\begin{array}{l}31 \text { March and } \\
09 \text { April }\end{array}$ & $\mathrm{H}-\mathrm{B}$ & $\begin{array}{l}\text { W-B1 } \\
\text { W-B2 } \\
\text { W-B3 }\end{array}$ & F-H-B & F-W-B \\
\hline 2016 & $\begin{array}{l}543072634 \\
543078625 \\
543062391^{* *}\end{array}$ & C & $\begin{array}{l}08 \text { May and } \\
16 \text { May* }\end{array}$ & $\mathrm{H}-\mathrm{C}$ & $\begin{array}{l}\text { W-C1 } \\
\text { W-C2 } \\
\text { W-C3 }\end{array}$ & $\mathrm{F}-\mathrm{H}-\mathrm{C}$ & F-W-C \\
\hline 2018 & FE AA48 15232 & D & 04 September & $H-D$ & W-D & F-H-D & F-W-D \\
\hline
\end{tabular}

* Ponies were put on pasture after 16 May 2018

** Batch fed to haylage-ponies the day before faeces sampling 
571 Table 2 Qualitative detection of fungi in the different hay $(\mathrm{H})$, wrapped haylage (W) and faeces (F) samples 572 collected at different dates (A-D) with the most prevalent fungal species marked with $\bullet$.

573

\begin{tabular}{|c|c|c|c|c|c|c|c|c|c|c|c|c|c|c|c|c|c|c|c|c|}
\hline \multirow[b]{2}{*}{ Fungi } & \multicolumn{4}{|c|}{ Hay (H) } & \multicolumn{4}{|c|}{ Faeces-Hay (F-H) } & \multicolumn{8}{|c|}{ Haylage (W) } & \multicolumn{4}{|c|}{ Faeces-haylage (F-W) } \\
\hline & $A$ & $\mathrm{~B}$ & $\mathrm{C}$ & $\mathrm{D}$ & $A$ & $B$ & $\mathrm{C}$ & $\mathrm{D}$ & A & B1 & $\mathrm{B} 2$ & B3 & $\mathrm{C} 1$ & $\mathrm{C} 2$ & $\mathrm{C3}$ & $\mathrm{D}$ & $\mathrm{A}$ & $\mathrm{B}$ & $\mathrm{C}$ & $\mathrm{D}$ \\
\hline \multicolumn{21}{|l|}{ Aspergillus } \\
\hline Asp. cristatus & - & - & - & - & - & - & - & - & - & - & + & - & - & - & - & - & - & - & - & - \\
\hline Asp. flavus & + & - & - & - & - & - & - & - & - & - & - & - & - & - & - & - & - & - & - & - \\
\hline Asp. fumigatus & + & + & + & - & - & - & - & - & - & - & - & + & - & - & - & - & - & - & - & - \\
\hline Asp. glaucus & + & $\bullet$ & + & - & $\bullet$ & $\bullet$ & $\bullet$ & - & - & - & - & - & - & - & - & - & + & + & - & - \\
\hline Asp. montevidensis & + & + & $\bullet$ & - & $\bullet$ & - & $\bullet$ & - & - & - & - & - & - & - & - & - & - & - & - & - \\
\hline Asp. niger & - & - & + & - & + & - & - & - & - & - & - & - & - & - & - & - & - & - & - & - \\
\hline Asp. pseudoglaucus & $\bullet$ & $\bullet$ & + & - & - & $\bullet$ & - & - & - & - & - & + & + & - & - & + & + & - & + & - \\
\hline Asp. versicolor & - & - & - & - & + & + & + & - & - & - & - & - & - & - & - & - & - & - & - & - \\
\hline \multicolumn{21}{|l|}{ Penicillium } \\
\hline Pen. astrolabium & - & - & - & - & - & - & - & - & - & - & - & - & - & - & - & - & $\bullet$ & - & - & - \\
\hline Pen. brevicompactum & - & - & + & - & - & + & - & - & - & - & - & - & - & - & - & - & - & - & - & - \\
\hline Pen. chrysogenum & - & - & + & - & + & - & - & - & - & - & - & - & - & - & - & - & - & - & - & - \\
\hline Pen. commune & - & - & - & - & - & + & + & + & - & - & - & - & - & - & - & + & + & + & + & + \\
\hline Pen. crustosum & $\bullet$ & - & - & - & + & - & - & + & - & - & - & $\bullet$ & - & - & - & - & + & - & + & + \\
\hline Pen. echinulatum & - & - & - & - & - & + & - & - & - & - & - & - & - & - & - & + & - & - & + & - \\
\hline Pen. expansum & - & - & - & - & + & $\bullet$ & $\bullet$ & + & - & - & - & - & - & - & - & - & + & $\bullet$ & $\bullet$ & + \\
\hline Pen. majusculum & - & - & - & - & - & - & + & - & - & - & - & - & - & - & - & - & - & - & + & - \\
\hline Pen. palitans & - & - & - & - & + & + & + & - & - & - & - & - & - & - & - & - & - & - & + & - \\
\hline Pen. polonicum & - & + & - & - & - & + & - & - & - & - & - & - & - & - & - & - & - & - & - & - \\
\hline Pen. roqueforti & - & - & - & - & - & - & - & - & $\bullet$ & + & - & - & $\bullet$ & $\bullet$ & + & - & - & - & + & - \\
\hline Pen. solitum & - & + & + & - & - & + & + & - & - & - & - & - & - & - & - & - & $\bullet$ & $\bullet$ & $\bullet$ & - \\
\hline Pen. verrucosum & - & - & - & - & - & - & + & - & - & - & - & - & - & - & - & - & - & - & - & - \\
\hline
\end{tabular}

\section{Field and other fungi}

Alternaria spp.

Arthrinium spp.

Cephalotrichum sp.

Chaetomium globosum

Chrysosporium sp.

Cladosporium spp.

Engyodontium album

Epicoccum nigrum

Fusarium poae

Harzia acremonioides

Nigrospora sp.

Phoma spp.

Sordaria fimicola

Paecilomyces variotii

Wallemia sebi

Zygomycetes

Yeasts

Sterile mycelium

* See Table 1 for collection dates and details.

This is a pre-print of an article published in Mycotoxin Research. The final authenticated version is available online at: https://doi.org/10.1007/s12550-019-00377-5. Page 27 
575 Table 3 Qualitative detection of fungi $(\bullet)$ and metabolites (+) in the wrapped haylage hot spot (W-hs) collected in 2013 (W-hs-1 to 3), 2014 (W-hs-4 to 6) and 2016 (W-hs-7).

577

\begin{tabular}{|c|c|c|c|c|c|c|c|}
\hline \multirow[b]{2}{*}{ Fungi/metabolites } & \multicolumn{7}{|c|}{ Haylage hot spot } \\
\hline & W-hs-1 & W-hs-2 & W-hs-3 & W-hs-4 & W-hs-5 & W-hs-6 & W-hs-7 \\
\hline Penicillium roqueforti & $\bullet$ & $\bullet$ & $\bullet$ & $\bullet$ & $\bullet$ & $\bullet$ & $\bullet$ \\
\hline (+)-Aristolochene & - & - & + & - & - & - & - \\
\hline Andrastins $B$ and $C$ & - & - & + & + & + & + & - \\
\hline Costaclavin & - & - & + & - & - & - & - \\
\hline Eremofortin A & - & + & - & - & - & - & - \\
\hline Mycophenolic acid & + & + & - & - & - & - & - \\
\hline PR toxin & - & + & - & - & - & - & - \\
\hline Isofumigaclavin A & - & - & + & - & - & - & - \\
\hline Roquefortines C and D & - & - & + & + & + & + & - \\
\hline Pen. paneum & - & - & - & $\bullet$ & $\bullet$ & $\bullet$ & $\bullet$ \\
\hline Asperparaline A & + & + & + & + & - & - & - \\
\hline Marcfortine A & - & - & - & + & - & + & - \\
\hline Marcfortine B & - & - & - & + & + & + & - \\
\hline Marcfortine C & - & - & - & - & - & + & - \\
\hline Pen. solitum & $\bullet$ & $\bullet$ & - & - & - & - & - \\
\hline Viridicatols* & - & + & - & - & - & - & - \\
\hline Paecilomyces variotii & - & $\bullet$ & - & - & - & - & - \\
\hline Fusarium spp. & - & - & - & - & - & - & - \\
\hline Dehydrofusaric acid & - & - & + & + & - & + & + \\
\hline Wallemia sebi & - & - & - & - & - & - & - \\
\hline walleminol & - & + & + & - & - & - & - \\
\hline Sordariales spp. & - & - & - & - & - & - & - \\
\hline (-)-Musanahol & - & - & - & - & + & - & + \\
\hline 3-epi-Aureonitol & - & - & + & + & - & + & - \\
\hline Anserinone B & + & + & + & + & + & + & - \\
\hline Chaetoquadrin $\mathrm{F}$ and $\mathrm{I}$ & + & + & - & + & + & + & + \\
\hline Chaetospirone & + & - & + & - & - & - & - \\
\hline Chaetoxanthone B & + & + & + & - & + & + & + \\
\hline Coarctatin & - & - & - & + & + & + & - \\
\hline Communiols $\mathrm{B}, \mathrm{D}$ and $\mathrm{F}$ & + & + & + & + & - & + & - \\
\hline Gliocladic acid & + & + & + & - & - & + & - \\
\hline Globosumones A and B & - & - & - & + & - & + & - \\
\hline Heptacyclosordariolone & + & - & - & - & - & + & - \\
\hline Hydroxysordarin & - & - & - & + & - & - & - \\
\hline Sordaricin & - & - & - & - & + & - & - \\
\hline Sordarin & + & + & - & - & - & - & - \\
\hline $\begin{array}{l}\text { Yeast spp. } \\
\text { All fungal spp. }\end{array}$ & - & - & $\bullet$ & $\bullet$ & - & - & $\bullet$ \\
\hline Ergosterol & + & + & + & + & + & + & + \\
\hline Linoleic acid & + & + & + & + & + & + & + \\
\hline
\end{tabular}

* All precursors (cyclopenins and viridicatin) to viridicatol were detected in sample W-hs-2.

This is a pre-print of an article published in Mycotoxin Research. The final authenticated version is available online at: https://doi.org/10.1007/s12550-019-00377-5. Page 28 
579 Table 4 Qualitative detection of metabolites and their producers in the different hay $(\mathrm{H})$, wrapped haylage 580 (W) and faeces (F) from ponies fed either hay or haylage collected at different dates (A-D).

\begin{tabular}{|c|c|c|c|c|c|c|c|c|c|c|c|c|c|c|c|c|c|c|c|c|}
\hline \multirow[b]{2}{*}{ Fungi/metabolites } & \multicolumn{4}{|c|}{ Hay (H) } & \multicolumn{4}{|c|}{ Faeces-Hay (F-H) } & \multicolumn{8}{|c|}{ Haylage (W) } & \multicolumn{4}{|c|}{ Faeces-haylage (F-W } \\
\hline & $A$ & $B$ & $\mathrm{C}$ & $\mathrm{D}$ & $A$ & $B$ & $\mathrm{C}$ & $\mathrm{D}$ & A & B1 & B2 & B3 & $\mathrm{C} 1$ & $\mathrm{C} 2$ & C3 & $\mathrm{D}$ & $A$ & $\mathrm{~B}$ & $\mathrm{C}$ & $\mathrm{D}$ \\
\hline \multicolumn{21}{|l|}{ Aspergillus spp. } \\
\hline Emodins & + & + & + & - & - & - & - & - & - & - & - & - & - & + & + & + & - & - & - & - \\
\hline Nigragillin & - & - & + & - & - & - & - & - & - & - & - & - & + & + & + & - & - & - & - & - \\
\hline
\end{tabular}

\section{Fusarium spp.}

Enniatins

Sambucinol

\section{Monascus spp.}

Dihydromonacolin

\section{Penicillium spp.}

B-cyclopiazonic acid

Asperparaline $A$

Asperphenamate

Eremofortin A

Isofumigaclavin A

Penicillic acid

Roquefortine $C$

Rugulovasin A

Wallemia sebi

walleminol

\section{Sordariales}

3-epi-aureonitol

Anserinones

Appenolides

Chaetoquadrins

Chaetoxanthones

Coarctatin

Cochliodinol

Communiols

Gliocladic acid

Globosumones

Heptacyclosordariolone

Hydroxysordarin

Longirostrerones

Sordaricin

Sordarin

\section{All fungal spp.}

Ergosterol

* See Table 1 for collecting dates and details.

This is a pre-print of an article published in Mycotoxin Research. The final authenticated version is available online at: https://doi.org/10.1007/s12550-019-00377-5. Page 29 

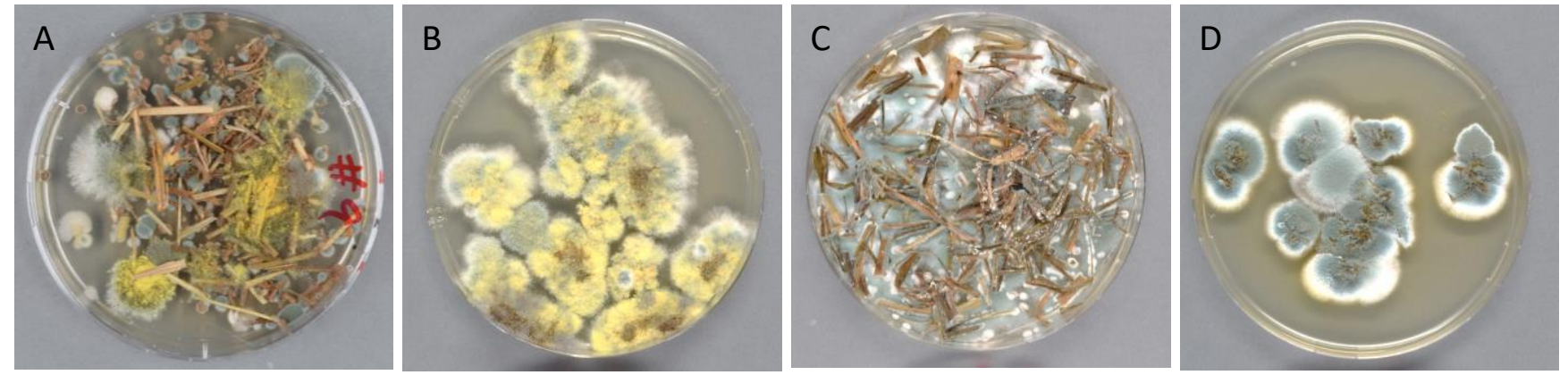

584 Fig. 1 Forage and faeces samples from spring. Direct plating on DG18. A: Hay (H-A), B: Faeces from pony \#1 585 fed hay (F-H-A), C: Haylage (W-C2) and D: Faeces from pony \#14 fed haylage (F-W-C).
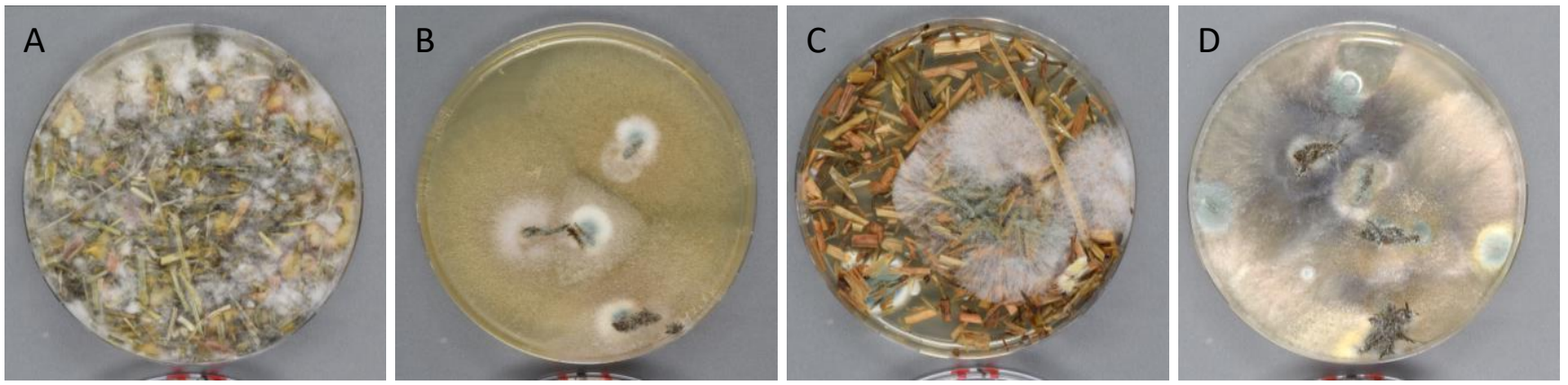

Fig. 2 Forage and faeces samples from autumn. Direct plating on DG18. A: Hay (H-D), B: Faeces from pony

\#1 fed hay (F-H-D), C: Haylage (W-D) and D: Faeces from pony \#14 fed haylage (F-W-D). 
Loadings

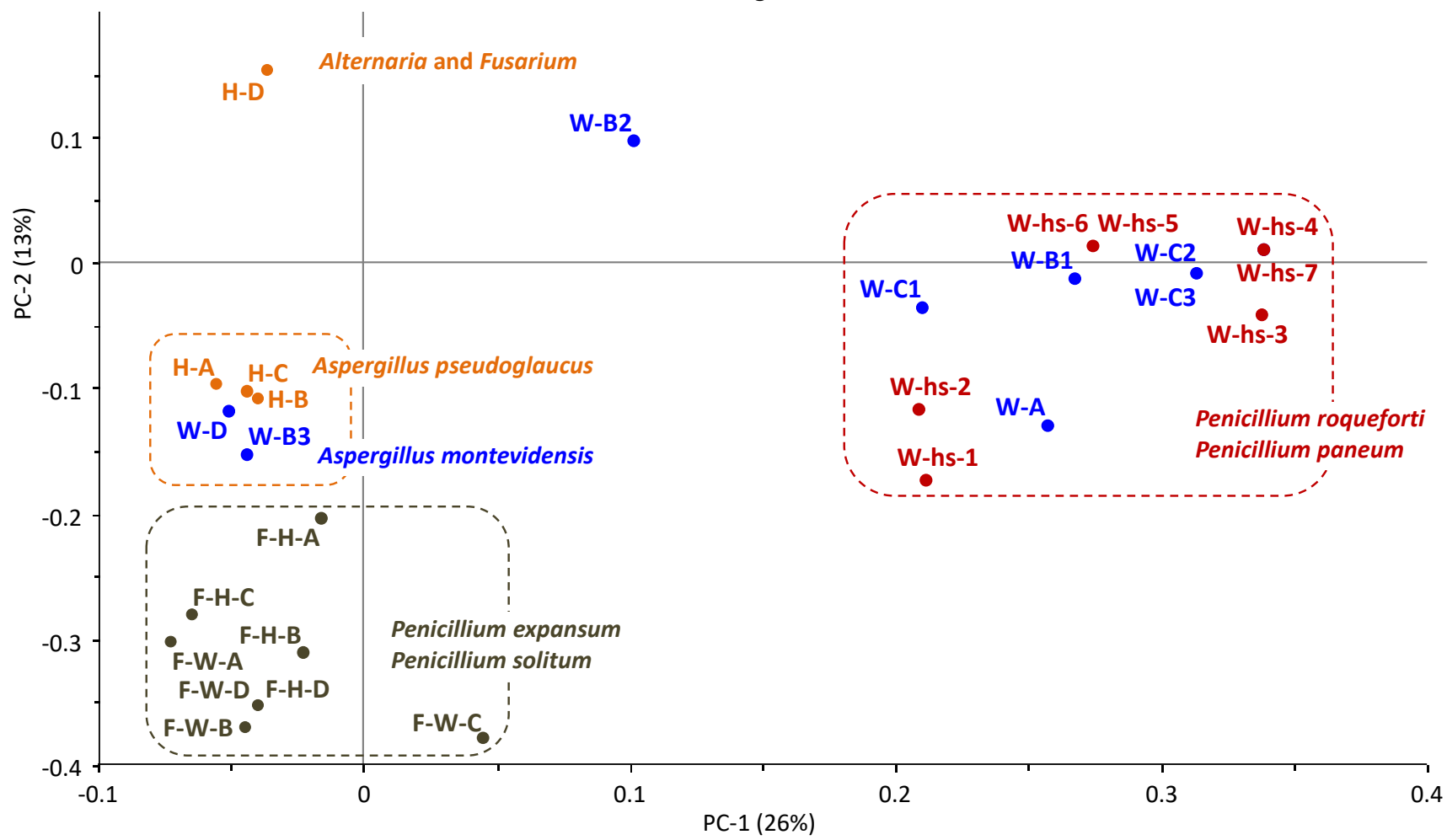

592 Fig. 3 A Principal Component Analysis of the qualitative fungal biota on hay (H), haylage (W) and faeces (F) 593 samples collected early spring (A), intermediate (B and C) and early autumn (D) in 2018. The haylage hot 594 spot (W-hs) samples have been collected in 2013-2016. The most prevalent fungi are given for each sample 595 group. The analysis is based on 27 samples (objects) and 48 fungal species (variables/factors) detected in 596 the samples. Arbitrary axis.

This is a pre-print of an article published in Mycotoxin Research. The final authenticated version is available online at: https://doi.org/10.1007/s12550-019-00377-5. Page 31 


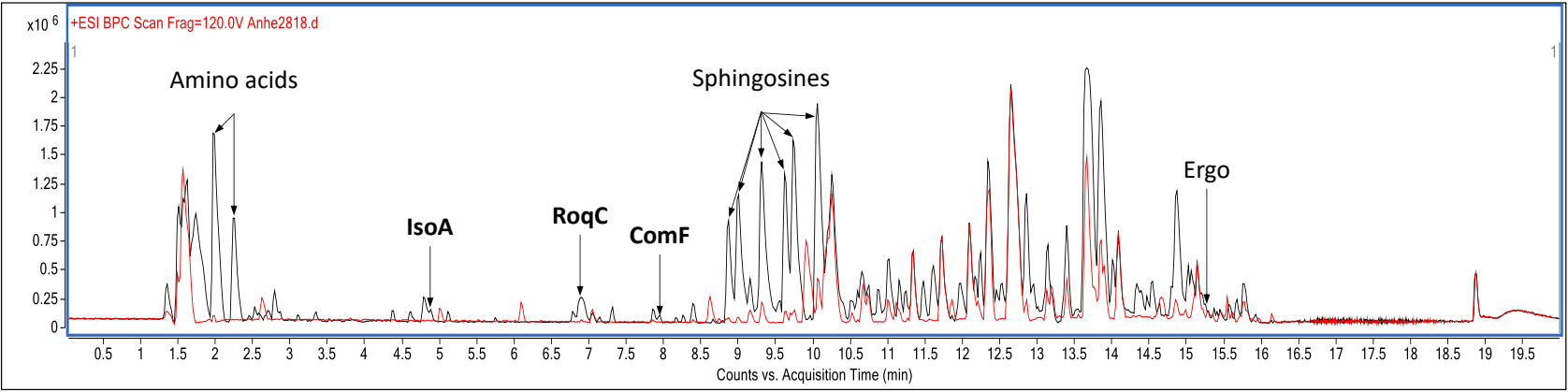

598

599 Fig. 4 Liquid Chromatography chromatograms of haylage sample W-C2 (black line) and hay sample H-C (red 600 line). The majority of compounds (peaks) are plant compounds, like the sphingosines. Three fungal 601 metabolites are marked: Isofumigaclavine $A$ (IsoA), roquefortine C (RoqC) in the haylage and communiol $F$ 602 (ComF) and ergosterol (Ergo) in both haylage and hay. The peaks of communiol F and ergosterol are higher 603 in the haylage than in the hay. 


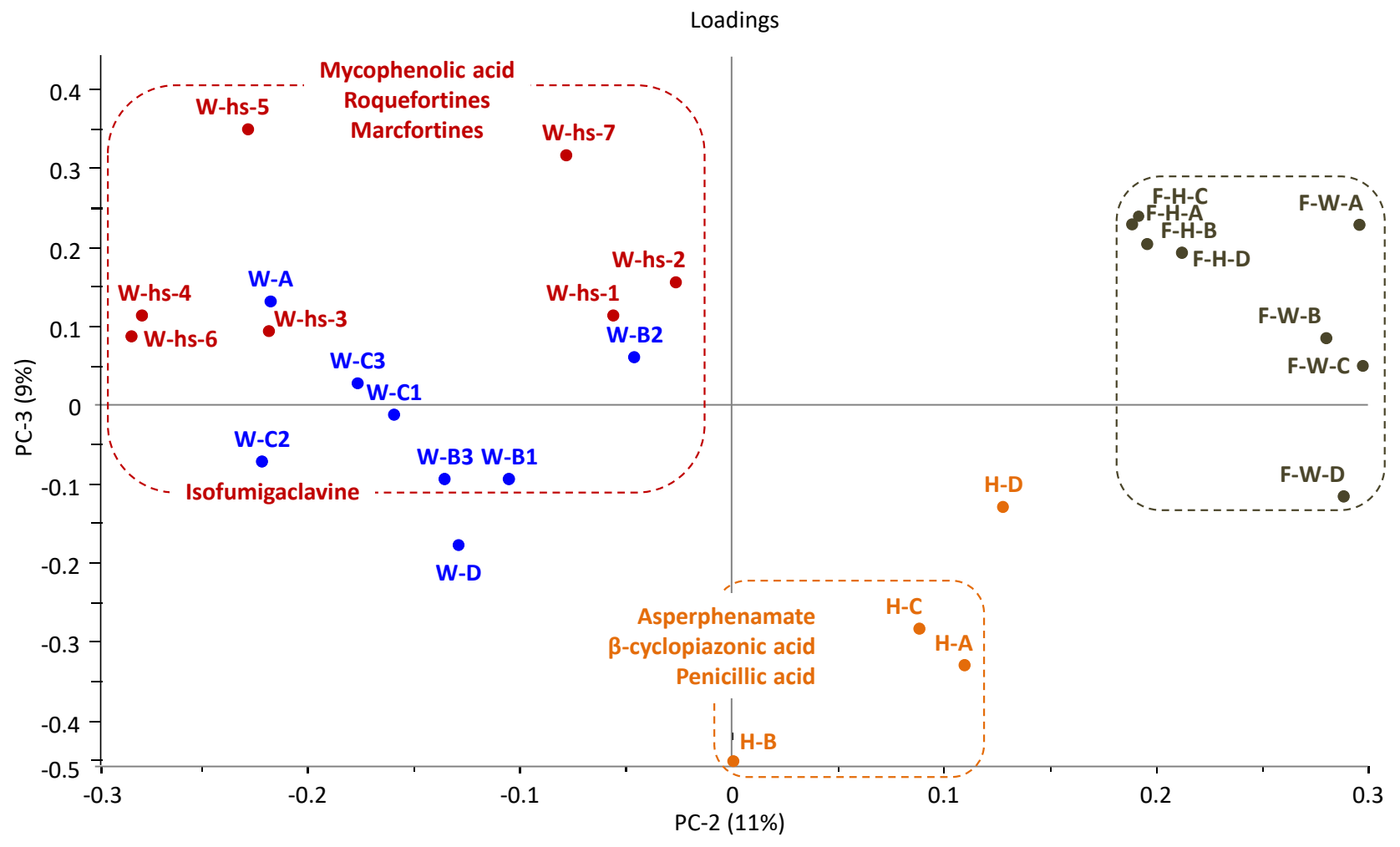

604

605 Fig. 5 A Principal Component Analysis of the qualitative metabolite production on hay $(\mathrm{H})$, wrapped haylage 606 (W) and faeces (F) samples collected early spring (A), intermediate (B and C) and early autumn (D) in 2018.

607 The haylage hot spot (W-hs) samples have been collected in 2013-2016. Key fungal metabolites are given for 608 each sample group. The analysis is based on 27 samples (objects) and 93 mycotoxins and other compounds 609 (variables/factors) detected in the samples. Arbitrary axis.

This is a pre-print of an article published in Mycotoxin Research. The final authenticated version is available online at: https://doi.org/10.1007/s12550-019-00377-5. Page 33 